\title{
Temporal and Spatial Effects on Some Physiological Parameters of the Bivalve Lithophaga lithophaga (Linnaeus, 1758) from Coastal Regions of Alexandria, Egypt
}

\author{
Eman Hashem Radwan ${ }^{*}$, Sherifa Shaker Hamed ${ }^{2,3}$, Gaber Ahmed Saad ${ }^{3,4}$ \\ ${ }^{1}$ Department of Zoology, Faculty of Science, Damnhour University, El Behara, Egypt \\ ${ }^{2}$ Department of Zoology, College of Science, King Saud University, Saudi Arabia, KSA \\ ${ }^{3}$ Department of Zoology, Faculty of Science, Alexandria University, Alexandria, Egypt \\ ${ }^{4}$ Department of Biology, College of Medicine, Dammam University, Saudi Arabia, KSA

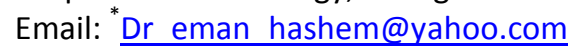

Received 2 July 2014; revised 4 August 2014; accepted 15 August 2014

Copyright (C) 2014 by authors and Scientific Research Publishing Inc.

This work is licensed under the Creative Commons Attribution International License (CC BY). http://creativecommons.org/licenses/by/4.0/

\section{(c) (i) Open Access}

\begin{abstract}
The date clam, Lithophaga lithophaga is a popular edible bivalve. It was collected from three different locations (Abo-Quir, Miami and El-Mex) along the coast of Alexandria-Egypt to determine the effect of two heavy metals as copper ( $\mathrm{Cu}$ ) and cadmium (Cd). The three organs were selected: gill, mantle and digestive gland. The enzymatic change is correlated with the concentration of metals. The present results suggest that Miami water is less polluted with $\mathrm{Cu}$ and $\mathrm{Cd}$ as compared to the two other locations. The physicochemical parameters are not significant among the three locations. Water of Abu-Quir and El-Max may be hazardous to bivalves. The order of levels of $\mathrm{Cu}$ and Cd was: gill > digestive gland > mantle. The present study illustrated that, in Abu Quir, there was a high positive correlation between $\mathrm{Cd}$ and Succinate dehydrogenase $(\mathrm{SDH})$ as $r=0.969$ whereas $\mathrm{Cu}$ and $\mathrm{SDH}$ as $\mathrm{r}=\mathbf{- 0 . 9 1}$.
\end{abstract}

\section{Keywords}

Lithophaga lithophaga, Heavy Metals, Cu, Enzyme Activities

\section{Introduction}

Pollution of the aquatic environment by heavy metals has received considerable attention in recent years. Ele-

${ }^{*}$ Corresponding author.

How to cite this paper: Radwan, E.H., Hamed, S.S. and Saad, G.A. (2014) Temporal and Spatial Effects on Some Physiological Parameters of the Bivalve Lithophaga lithophaga (Linnaeus, 1758) from Coastal Regions of Alexandria, Egypt. Open Journal of Ecology, 4, 732-743. http://dx.doi.org/10.4236/oje.2014.412063 
vate concentrations of metals in aquatic ecosystems can be caused by the release of sewage and industrial effluents, non-point source runoff from agricultural and urban areas, and atmospheric fallout. When heavy metals enter the aquatic ecosystems, their mechanisms can cause stress effects due to their ability to accumulate [1]. [2] reported that cadmium sources in the anthropogenic sites came from ship traffic and tourist boats. The major environmental problem in the coastal area is directly related to the impact of domestic effluents [3]. The origin of trace elements in the sampled water of the Egyptian Mediterranean is mainly the waste water discharge [4]. Element concentrations in mollusks at the same location differ between different individuals [5] and different animals in the same community at the same trophic level could accumulate pollutants differently [6]. [7] said that the excess metal accumulation had the potential to exert toxic effects including cellular toxicity in bivalves.

The aim of the present study relates the concentration of heavy metal pollution in the coastal water on the physiology of a bivalve (Lithophaga lithophaga). Three localities from the Mediterranean Sea, Alexandria and Egypt were chosen for this study (Abo Quir, Miami and El-Mex). Specimens were collected seasonally throughout the year 2011(January 2011-December 2011). The present study aims also to: assess the level of copper and cadmium in seawater collected from three different locations; assess the level of these metals in different organs (gills, mantle and digestive gland); and investigate the impact of these metals on the enzymatic status of these organs.

\section{Materials and Methods}

\subsection{Study Area}

Localized pollution problems are mainly due to increasing coastal development activities including large urbanization and industrial development. The three locations were chosen: Abo Quir, Miami and El Mex. Water and mollusk samples were collected from these stations seasonally during the year, 2011, no.250/location/season.

\subsection{Sampling}

\subsubsection{Water Samples}

Coastal water samples were collected from the three selected locations on the coast of the Alexandria at $3-5 \mathrm{~m}$ depth for the determination of copper, and cadmium. Seawater samples were filtered through $0.45 \mu \mathrm{m}$ millipore filters to remove any debris particles then stored at $-20^{\circ} \mathrm{C}$ until analysis. All concentrations are reported as $\mu \mathrm{g} / \mathrm{L}$ for seawater. All the precautions recommended by [8] to minimize risks of sample contamination were followed during collection and treatment of samples.

\subsubsection{Mollusk Samples}

The Bivalve Lithophaga lithophaga (20 - 25 gm, 9 - $10 \mathrm{~cm}$ shell length, antero-posterior axis), were collected in sterile plastic bag (no.250/location/season, replicant, 5 times) and were cleaned from attached organisms and then rinsed with seawater from their sampling locations and transported to the laboratory within 4 - 6 hrs.

\subsection{Analytical Methods}

\subsubsection{Heavy Metals in Seawater}

The concentration of $\mathrm{Cu}$, and $\mathrm{Cd}$ were determined in the collected seawater samples using Graphite Furnace Atomic Absorption Spectroscopy (Perkin-Elmer model 2380) under the recommended conditions and the detection limits in the manual for each metal [9].

\subsubsection{Physicochemical Analysis of Seawater}

Surface water samples were collected five times; bi-week from three sites representing the coastal area in front of Alexandria city starting from Abo-Quir, at the east, Miami, and El-Mex at the west. At each location water samples were collected using polyethylene bottles (2-liters capacity). The polyethylene bottles were previously cleaned with detergent rinsed several times with distilled water, soaked in $1 \mathrm{~N} \mathrm{HCl}$ for several days and finally rinsed with re-distilled water. At each site a $150 \mathrm{~mL}$ dissolved oxygen bottle was firstly filled and immediately fixed, using manganoussulphate and alkaline potassium iodide solution [10]. Some parameters were totally or partially measured in the field i.e. as soon as the sample was collected. These steps of the methods would be explained by the term "in situ" in the text. Temperature measurements: In situ at each station, air and water temperatures were measured at the time of water sampling using an ordinary thermometer. Salinity (S\%): Salinity 
was determined by measuring the electrical conductivity using an inductive Salinometer (Beckman; model RS. 10). Hydrogen-ion concentration $[\mathrm{pH}]$ : The $\mathrm{pH}$-value of water sample was measured in the laboratory immediately after collection using Bench type (JENWAY, 3410 Electrochemistry Analyzer pH-meter). Dissolved oxygen (DO): It was determined by a modified Winkler’s method [10].

\subsection{Analysis of Physiological Parameters}

1) Superoxide dismutase (SOD): Antioxidative enzyme activities determination: Tissue cell suspension was separated on an ice-cold surface. Tissue cell suspension homogenates were prepared. Superoxide dismutase is measured based on [11].

2) Glutathione-S-transferase (GST): Activities of the following enzyme in the extracts were determined spectrophotometricaly using a Spectra MAX 340 microplate reader. GST activity was determined using a modified method of [12].

3) GPX activity: (nmol/min/mg protein) was measured using an adaptation of the method of [13].

4) Succinic dehydrogenase (SDH) is measured by [14].

\subsection{Heavy Metals in Tissue}

The preparation of samples to determine concentration of heavy metals was carried out animals were separated from the shells; weighed and digested using conc. $\mathrm{HNO}_{3}$ in Taflon digestion vessels. Wet digested samples were diluted with deionized distilled water and analyzed by Ion-selective electrod AVL. The obtained data were expressed as $\mu \mathrm{g} / \mathrm{g}$ wet weight [6]. The analytical method was checked by (5 replicate) measurements for the studied metals in a sample of marine.

\subsection{Statistical Analysis}

Statistical analysis was performed using two-way ANOVA using SPSS computer program (version 14.0) to check for significant difference between metal concentrations in different localities.

\section{Results and Discussion}

The results of the present study showed that there was incraese in $\mathrm{Cu}$ in seawater in Abo Quir as $2.45>\mathrm{El}$ Mex as $1.56>$ Miami as 1.4 whereas for Cd, the highest results was represented also in Abo Quir as $1.82>$ El Mex as $1.0>$ Miami as 0.4 , (Table 1 ).

In the current study, the physicochemical parameters for temperature, the highest mean reading was, in Miami as $29.7>$ El Mex as $28.8>$ Abo Quir 28.5. For the salinity, the highest value was reported at Miami as 38.8 comparing to El Mex as 38.2 > Abo Quir as 38.7, (Table 2). $\mathrm{pH}$ recorded the highest value in both El Max and Miami as $8>$ Abo Quir as 7.44. The dissolved oxygen was recording the highest mean level in Miami as 5.74 followed by both El Mex and Abo Quir as 5.1, (Table 2).

For physicochemical parameters of seawater the highest mean of salinity was reported as Abo Quir $>$ El Mex > Miami, whereas, for the mean of temperature, DO, $\mathrm{pH}$, the highest mean level was as Miami $>\mathrm{El}$ Mex > Abo Quir (Table 2). For $\mathrm{Cu}$ in gills, the highest mean reading was found in Miami as 6.0 followed by El Mex as 4.4 then Abo Quir as 3.4 and the $\mathrm{Cu}$ in mantle reported the highest mean reading in Miami as 2.6 followed by both Abo Quir and El Mex as 0.8. The mean $\mathrm{Cu}$ in the digestive gland, the highest mean reading was reported as 4.3 in Miami followed by Abo Quir as 2.9 then El Mex as 2.5 (Table 3). The mean of Cd in gills was reported as 3.4 in Miami $>0.97$ in El Mex followed by Abo Quir as 0.8 whereas for Cd in mantle, the highest reading was reported in Miami as $1.7>\mathrm{El}$ Mex as 1.4 then Abo Quir as 0.5. For Cd in the digestive gland, the highest mean reading was reported in Miami as 2.4 > El Mex as1.9 then > Abo Quir as 1.1 (Table 3).

In the current study, the mean level of SDH concentration in gills highly significant increase in El Mex > Miami > Abo Quir whereas, for mean concentration level of GST in gills reported highest level in Abo Quir > El Mex > Miami. The highest level of concentration of GPx in gills reported in Abo Quir > El Mex > Miami whereas, the highest mean concentration level of SOD in gills, was reported as Abo Quir $>$ Miami $>$ El Mex. In the present study, the highest concentration level of SDH in mantle was as followed, El Mex $>$ Miami $>$ Abo Quir, whereas GST concentration level in the mantle reported as El Mex > Abo Quir > Miami, (Figures 1-3).

The high mean concentration level of GPx has no significant difference between the three locations, whereas 
Table 1. Heavy metal concentration $(\mu \mathrm{g} / \mathrm{L})$ in the three study areas along Alexandria coast.

\begin{tabular}{|c|c|c|c|c|}
\hline Heavymetals/locations & Abo Quir & Miami & El Max & Admissible levels of heavy metals \\
\hline $\mathrm{Cu}(\mu \mathrm{g} / \mathrm{L})$ & $2.45 \pm 0.54$ & $1.40 \pm 0.44$ & $1.56 \pm 0.26$ & $\begin{array}{c}3.1(\mu \mathrm{g} / \mathrm{L}) \\
\text { USEPA(2005) }\end{array}$ \\
\hline $\mathrm{Cd}(\mu \mathrm{g} / \mathrm{L})$ & $1.82 \pm 0.23$ & $0.42 \pm 0.28$ & $1.03 \pm 0.20$ & $\begin{array}{c}40(\mu \mathrm{g} / \mathrm{L}) \\
\text { USEPA }(2005)\end{array}$ \\
\hline
\end{tabular}

Table 2. Physicochemical parameters of seawater collected from the three study areas along Alexandria coast.

\begin{tabular}{cccc}
\hline Physicochemical parameters/location & Abo Quir & Miami & El Mex \\
\hline Temperature & $28.52 \pm 0.49$ & $29.7 \pm 1.33$ & $28.76 \pm 0.58$ \\
Salinity (mg/L) & $38.72 \pm 0.15$ & $38.16 \pm 0.21$ & $38.24 \pm 0.15$ \\
pH & $7.44 \pm 0.36$ & $8.14 \pm 0.19$ & $8.0 \pm 0.06$ \\
Dissolvedoxygen (DO) (mg/L) & $5.16 \pm 0.18$ & $5.74 \pm 0.13$ & $5.10 \pm 0.14$ \\
\hline
\end{tabular}

Table 3. Heavy metal concentration $(\mu \mathrm{g} / \mathrm{g})$ in some organs of Lithophaga lithophaga (in wet weight) collected from the three study areas along Alexandria coast.

\begin{tabular}{cccc}
\hline Heavy metals/location & Abo Quir & Miami & El Mex \\
\hline Cu & & & $4.36 \pm 0.26$ \\
Gills & $3.35 \pm 0.18$ & $6.03 \pm 0.03$ & $0.81 \pm 0.07$ \\
Mantle & $0.76 \pm 0.03$ & $2.62 \pm 0.37$ & $2.54 \pm 0.33$ \\
Digestive glands & $2.86 \pm 0.05$ & $4.24 \pm 0.33$ & $0.97 \pm 0.13$ \\
Cd & & & $1.42 \pm 0.22$ \\
Gills & $0.79 \pm 0.15$ & $3.55 \pm 0.28$ & $1.88 \pm 0.13$ \\
Mantle & $0.47 \pm 0.08$ & $1.65 \pm 0.12$ & $2.44 \pm 0.30$ \\
\hline
\end{tabular}

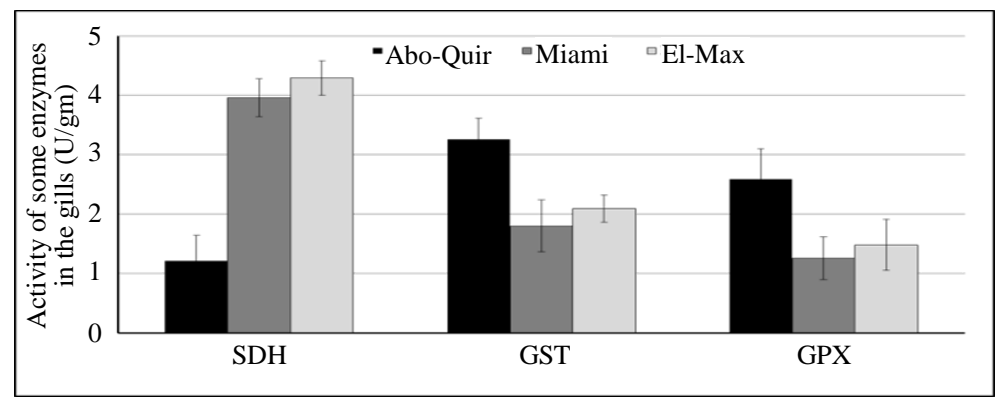

Figure 1. Activity of SDH, GST and GPx in gills of Lithophaga lithophaga.

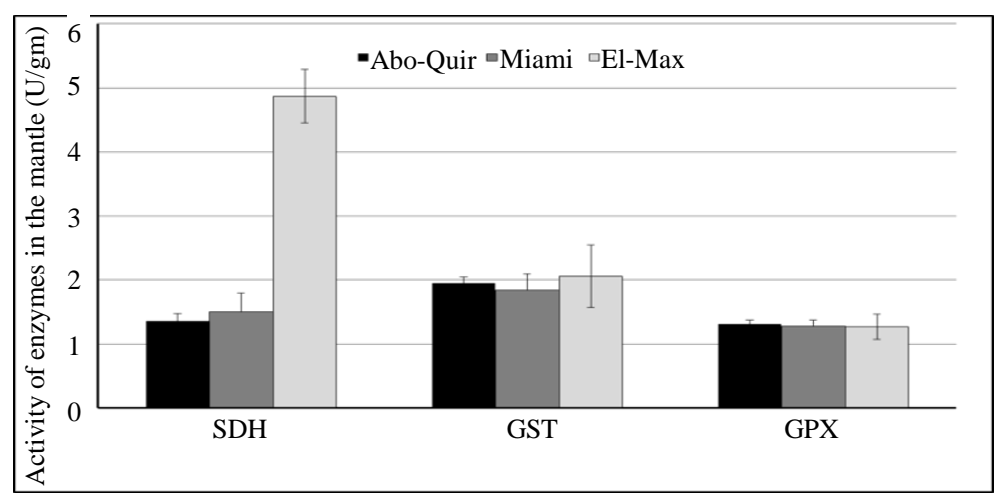

Figure 2. Activity of SDH, GST and GPx in mantle of Lithophaga lithophaga. 


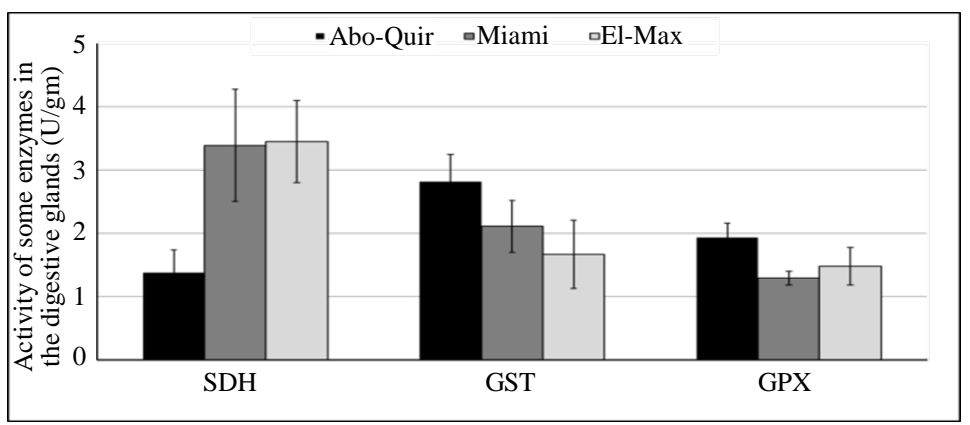

Figure 3. Activity of SDH, GST and GPx in digestive gland of Lithophaga lithophaga.

SOD highest mean concentration level in mantle was reported in Miami > El Mex > Abo Quir. The activity of some enzymes in the digestive gland was reported in the present study, the highest mean concentration level of SDH in the digestive glands was as El Mex > Miami > Abo Quir, whereas for GST in digestive gland was reported as Abo Quir > Miami > El Mex. The high concentration level of GPx in the digestive gland was reported as, Abo Quir > El Mex > Miami, whereas, for SOD it was reported as Abo Quir > Miami > El Mex, (Figures 1-3).

In the present study, the highest mean concentration level for GST, SOD, GPx in gills was reported in Abo Quir, whereas the highest concentration level of SDH was in El Mex. In the current study, for GST, SOD, GPx in the digestive glands, the highest reading was in Abo Quir whereas for SDH, the highest mean reading was reported in El Mex. For GPx in the mantle, the highest mean concentration level was reported in Abo Quir whereas for GST and SDH, the highest reading was in El Mex but SOD reported the highest concentration level in Miami. Table 4 illustrated that, in Abo Quir, there is high positive correlation between $\mathrm{Cd}$ and $\mathrm{SDH}$ as $\mathrm{r}=$ $0.969^{* *}$ whereas in Miami, there was high positive correlation between SOD and GST as $\mathrm{r}=0.937^{* *}$ but in El Mex, there was high negative correlation between $\mathrm{Cu}$ and SDH as $\mathrm{r}=-0.91^{* *}$ and also high negative correlation between Cd and GPx as $\mathrm{r}=-0.92^{* *}$.

Temperature, salinity, diet and individual variation are among other factors affecting accumulation of heavy metals [15]. [16] reported that all physiological mechanisms of response to cadmium differed at high and low cadmium levels. It is concluded here that there is no risk to eat date clam collected from Alexandria coast from the chosen locations as the levels of different heavy metal concentrations in tissues are below the safety levels reported by [17]. [6] reported that different animals in the same community at the same trophic levels could accumulate pollutants differently due to differences in habitat physical and chemical properties.

Variations in heavy metals concentration may be caused by factors such as a difference in seawater temperature, and food supply for the population of Mytilus galloprovincialis [18]. [16] and [19] agreed on that the temperature of the ambient water influences the metabolic rate of the organisms and hence the uptake and release of contaminants. Temperature may affect the growth, distribution of aquatic organisms. [19] and [20] reported that in temperature climates, oysters start to accumulate glycogen before winter and that, metal accumulation in the oyster soft tissues has little toxic effect on overall metabolism. [21] recorded $\mathrm{pH}$-values of water at Abu-Quir site as (7.57 - 8.26). They added that the decrease in $\mathrm{pH}$-value is coincided with the drop in oxygen content due to the effect of discharge of brackish water whereas, [22] reported that the values of hydrogen-ion concentration $\mathrm{pH}$ showed high concentration at the Eastern section of coast Mediterranean sea. The increase and decrease of $\mathrm{pH}$ values may be due to the mixed drainage water at the represented sites [23]. [21] reported that $\mathrm{pH}$-value decreases with the increasing distance from the points of discharge. He recorded the $\mathrm{pH}$-value in the El-Mex Bay as 8.06, whereas Abu-Quir Bay recorded $\mathrm{pH}$-value as 7.76. $\mathrm{pH}$ concentration may be highly significant factor in determining or limiting the threshold concentration. [22] reported that dissolved oxygen is considered as one of the most important and useful parameters in identification of different water masses and in assessing the degree of pollution. The maximum value of DO can be attributed to lower water temperature as well as strong winds [22]. The relationship between temperature and DO is reversed [23]. Salinity reflects the degree of contamination in aquatic environment [22]. El-Mex Bay area exhibited wide fluctuation in salinity affected by discharge of huge amounts of agricultural, sewage and industrial waste waters [24]. At S\%o was equal 30 ppm, clams may be releasing a protein due to the stress, they under that may cause cloudiness [25]. 
Table 4. Correlation coefficient of $\mathrm{Cu}$, Cd and enzyme activity of Lithophaga lithophaga in the three locations.

\begin{tabular}{|c|c|c|c|c|c|c|c|}
\hline Location & & & $\mathrm{Cd}$ & SDH & SOD & GST & GPx \\
\hline \multirow{5}{*}{ Abu Quir } & $\mathrm{Cu}$ & $\mathrm{r}$ & -0.304 & -0.309 & -0.237 & -0.769 & 0.79 \\
\hline & $\mathrm{Cd}$ & r & & $0.969^{*}$ & 0.317 & -0.153 & 0.004 \\
\hline & SDH & $\mathrm{r}$ & & & 0.504 & -0.211 & -0.116 \\
\hline & SOD & $\mathrm{r}$ & & & & -0.361 & -0.288 \\
\hline & GPx & $\mathrm{r}$ & & & & & -0.712 \\
\hline \multirow{5}{*}{ Miami } & $\mathrm{Cu}$ & $\mathrm{r}$ & 0.04 & 0.09 & -0.619 & -0.633 & 0.717 \\
\hline & $\mathrm{Cd}$ & $\mathrm{r}$ & & 0.169 & 0.240 & 0.112 & 0.03 \\
\hline & SDH & $\mathrm{r}$ & & & 0.416 & 0.161 & 0.501 \\
\hline & SOD & $\mathrm{r}$ & & & & $0.937^{*}$ & 0.579 \\
\hline & GST & $\mathrm{r}$ & & & & & -0.75 \\
\hline \multirow{5}{*}{ El Mex } & $\mathrm{Cu}$ & $\mathrm{r}$ & 0.34 & $-0.906^{*}$ & -0.615 & -0.695 & -0.038 \\
\hline & $\mathrm{Cd}$ & $\mathrm{r}$ & & -0.48 & 0.321 & -0.308 & $-0.917^{*}$ \\
\hline & $\mathrm{SDH}$ & $\mathrm{r}$ & & & 0.339 & 0.640 & 0.46 \\
\hline & SOD & $\mathrm{r}$ & & & & 0.695 & -0.326 \\
\hline & GST & $\mathrm{r}$ & & & & & 0.181 \\
\hline
\end{tabular}

[25] stated that variation in the physiology of marine animal might have affected the intake of metals by the organisms and that the effectiveness of metal intake may differ in relation to ecological needs and metabolism of animals and concentrations of the heavy metals in water and food as well as other factors such as salinity and temperature. [26] and [27] reported that a single biomarker cannot provide the basic answers as to what is the actual state of health in the natural populations and that, environmental stress may cause changes in cellular function that alter the physiology of organ system in organisms, suggesting that pollutants might influence the metabolism of the whole organism. [28] and [29] discovered a relationship between xenobiotic chemicals accumulated in oyster (Crassostrea virginica) tissue and various measures of physiological condition and that the possibility of variations of metals concentration due to physiological parameters have been taken into consideration such as stress. In the present study, variations of metal concentrations are to be attributed to variation of metal concentrations in the surrounding water.

In the present study the mean level of copper concentration in seawater of Abo-Quir was reported as, the highest mean level $(2.45 \mu \mathrm{g} / \mathrm{L})$ as comparing to the other locations, this might be due to leaching of copper from ships antifouling paints that could be a possible source for copper in Abo Quir. Abo Quir Harbor is affected by three continental discharges; they are; boughaz El-Maadia opening, the tapia pumping station and the opening of Rashid Nile branch [30]. In the present study Cu level for the three locations is lower than the Critirion Maximum Concentration (CMC) level for copper which is $4.8 \mu \mathrm{g} / \mathrm{L}$ and the Critirion Continous Concentration (CCC) level which is $3.1 \mu \mathrm{g} / \mathrm{L}$ stated by United State Enviromental Protection Agency [31]. [32] reported that the sources for Cd exposure are; air, water, other sources for Cd arise from the recycling and incineration of mincipal solid waste and hazardous wastes and pipe galvanization which are also abundant in the vicinity of polluted sites. [33] detected (40 $\mu \mathrm{g} / \mathrm{L})$ to be the criteria maximum concentration CMC for Cd. Sing of Cd in AboQuir in the present study is may be due to the biological activities, the industrial and sewage effluents.

In the present study the mean concentration of Cd is considered less than that reported by [34]. It is concluded that the coastal area in Mediterranean sea of Egypt might be considered relatively unpolluted with heavy metals this conclusion is in agreement with that of [35] who reported that; the coastal area in Mediterranean sea of Egypt might be considered relatively unpolluted with heavy metals. [2] [36] [37] reported that the uncontaminated sites recorded higher values compared to the human impact sites as well as it is suggested that, the deposition of contaminants into a marine area was due to transport of contaminants by coastal currents from upstream coastal industrial activities which is in agreement with the present study. [4] stated that the surface east water current and South west winds blowing on the Mediterranean coast of Egypt contribute mostly in spreading the trace elements to wide areas of the coast. The highest concentration of dissolved $\mathrm{Cu}$ at Alexandria coast may be due to the high decomposition rate of organic matter and the release of $\mathrm{Cu}$ from decaying organisms by the action of bacteria [25].

[27] found out that: the degree of environmental contamination is only one among several factors that influ- 
ence metal concentrations in animals. Bioavailablity or specific sources may be responsible for higher concentrations in apparently less impacted environments. [36] suggested that, the deposition of contaminants into a marine protected area was due to transport of contaminants by coastal currents from upstream coastal industrial activities. [36] noticed that gills were the only organ to exhibit a continued increase in the gills of clam tissue $\mathrm{Cu}$ concentration with the corresponding increase of $\mathrm{Cu}$ in the seawater. $\mathrm{Cu}$ concentrations were significantly high in the gills confirming that it is the main organ for metal bioaccumulation in Bathymodiolus azoricus (mussels) is the gills [3]. [37] and [38] reported that, $\mathrm{Cu}$ in the gills of Bathymodiolus azoricus and $\mathrm{Cu}$ in the gills of mussels from reference sites was higher when compared with similar tissues of coastal mussels, Mytilus edulis and Mytilus galloprovincialis from heavily polluted environments. The uptake of metals may take place at the gills of bivalve and that the gills function as a site of metal uptake [5]. [39] stated that, in Quebec, gills of fresh water bivalve (Pyganodon grandis) respond to metals Cu contamination gradient. [40] reported that, only gills of bivalves can be considered as an adequate target tissue for $\mathrm{Cu}$. The present study is in agreement with that conclusion as the gills were the target organ for $\mathrm{Cu}$ accumulation. Gills are frequent targets of environmental pollutants because they are the main interface between the organisms and their environment [41].

It had been suggested that the gill in Mussel Mytilus edulis appears to be more suitable organ for biomonitoring heavy metals [42] and that bivalves are frequently used in marine eco-toxicology for the purpose of assessing seawater quality because they are very sensitive to pollutants [43]. [37] reported that, the hepatopancreas of bivalve in the uncontaminated conditions demonstrates the highest values of toxic metals as a result of its major role in the uptake of metals from food. [44] reported that, gills are suggested as a possible route for accumulation of $\mathrm{Cd}$ as a possible route for $\mathrm{Cd}$ excretion. [45] reported $\mathrm{Cd}$ was present in the effluent and had accumulated significantly in mussels' gills. Metals could pose a health risk to heavy seafood consumers [46]. The average concentration of heavy metals found in Mussels were $0.64 \mu \mathrm{g} / \mathrm{g}$ for Cd [47]. [45] reported Cd accumulated significantly in mussels' gills. Uptake of metal in bivalves may take place at the gills and their relative importance is a function of the speciation of the metals in the environment [5]. The surveys of contaminants in shellfish conducted by Agency for Toxic Substances and Disease Registry [17] which reported the mean of Cd level for shellfish as $360 \mu \mathrm{g} / \mathrm{g}$ dry weight. [48] reported that there were different factors affecting the accumulation of metals in the bivalve species such as ambient concentrations of metals, growth rate, uptake and excretion rates of metals and biological development of animals. [4] reported that, the average concentrations of trace elements in Egyptian Mediterranean coast are far from the hazardous concentrations.

[44] suggested that, the gill appears to be a more suitable organ for bio monitoring than that the hepatopancreas. [37] [49] and [41] reported that gill represents the quick answer of mussels to water concentrations of metals. Every increase in dissolved Cd concentration in water resulted in a significant increase in its concentration in (Mussels) Dreissena polymorpha [31]. Any decrease in salinity makes a proportionately greater increase in the activity of the free cadmium ion [50]. The highest concentration of Cd was found in digestive gland in the clam Ruditapes philippinarium for Cd [40]. [38] reported the level of Cd level in the digestive gland of mussels collected from France as $0.05+0.01 \mu \mathrm{g} / \mathrm{g}$ wet weight. [51] found that $\mathrm{Cd}$ could be trapped in the digestive gland of the bivalves Crassostrea gigas (oyster). [42] found that when Ruditapes philippinarum (Bivalvia) were exposed to different concentrations of $\mathrm{Cd}(200-600 \mu \mathrm{g} / \mathrm{g})$; the highest concentrations for Cd were found in the digestive gland. [38] reported that in uncontaminated conditions, the hepatopancreas demonstrates the high toxic metals as a result of its major role in the uptake of metals from food and that the time of exposure is more important than the concentration of toxic metals. [27] reported that variation in the environmental conditions might have affected the intake metals by the organisms. Many metals were found in agricultural products, those present in fertilizers include Cd [5]. Cd accumulation can be considered a typically low concentration in many aquatic fauna relative to environmental levels [52]. This report is in agreement with the present data as levels of Cd in the gill, digestive gland and mantle tissue considered low according to [17].

The digestive gland is the main copper accumulation organ when oysters were exposing to low concentrations $(0.05 \mu \mathrm{M})$ [52]. [53] reported that the digestive gland appears as the center of accumulation of $\mathrm{Cu}$, as $\mathrm{Cu}$ is strongly accumulated in the digestive gland and that digestive gland is the main site of $\mathrm{Cu}$ accumulation in mollusk. The present study did not agree with that observation as gills represented the main site of $\mathrm{Cu}$ accumulation in Lithophaga lithophaga, whereas, [54] reported that the digestive gland of Mytilus edulis is the preferential organ for the accumulation of heavy metals. The uptake of metals may take place on the surface of the mantle of bivalve [5]. [33] reported that accumulation of $\mathrm{Cu}$ in mussel—soft tissue-from seawater of the Mediterranean sea—industerial and urban areas—showed a range of (3.89 - $16.56 \mu \mathrm{g} / \mathrm{g}$ dry weight). [55] reported that Cu tissue 
levels increased with exposure time reaching maximum levels after 24 days. [56] reported that metal concentrations recorded in the soft tissues of mussels Mytilus galloprovincialis increased without a source of extra metals in water. The average concentrations of $\mathrm{Cu}$ in all dissected organs, mantle, gills and digestive gland of Lithophaga lithophaga, in the present study, were lower than that stated by [17] $7800 \mu \mathrm{g} / \mathrm{g}$ for soft tissues of shellfish.

Very high Cd concentration may result from food chain bioaccumulation of elevated Cd levels brought into the productive surface water by upwelling into the region [57]. [58] reported Cd in Mytilus edulis which had been collected from Barents sea (Russia) are largely within a worldwide reported range ( 1 - $2 \mu \mathrm{g} / \mathrm{g}$ wet weight in Mytilus edulis. They hypothesized that a potential copper deficiency might be related to an increased uptake of Cd due to an insufficient selectivity of the uptake process for the essential element $\mathrm{Cu}$. [59] reported the mean of heavy metals in Pinctadaradiata collected from Akkuyu Bay (Icel Turkey—not polluted area) as $0.0058 \mu \mathrm{g}$ $\mathrm{Cd} / \mathrm{g}$ wet weight. They concluded that there was no heavy metal pollution in Akkuyu Bay Icel, Turkey. [60] stated that toxicity of Cd decreased with increasing the exposure time. [48] concluded that different factors can affect the accumulation of metals and its relationships in bivalve species such as food supply for the species population, growth rate and uptake and excretion rates of the metals. [33] reported that the effectiveness of metal uptake from food may differ in relation to ecological needs and concentration of the heavy metals in food. The irregular discharge of drainage water leads to variation in heavy metals concentrations [61].

Pollution in marine bivalve mollusks can induce effects on the immune system and thus diseases susceptibility can be enhanced [62]. [63] studied the expression of Glutathione peroxidase (GPx) that is known to be directly involved in oxidative metabolism and reported that, oxygen is at the basis of oxidative metabolism, genes encoding enzymes involved in the cellular regulation of oxidative stress such as antioxidants are consequently expected to be regulated by hypoxia. [64] found out that, aerobic organisms are protected against oxidative stress by antioxidant systems which mobiles enzymes such as the ( $\mathrm{Cu} / \mathrm{Zn}$ - superoxide dismutase) which transfers $\mathrm{O}_{2}$ to $\mathrm{H}_{2} \mathrm{O}_{2}$. The prooxidant effects of transition metals such as $\mathrm{Cu}$ on marine organisms have been assessed showing that these metals can induce oxyradical production leading to lipid peroxidation [65]. [41] reported that, there were some evidence for oxidative stress was noted in the gills of fresh water bivalve (Pyganodon grandis) in Quebec but not in the digestive gland. [63] studied the expression of GPx that is known to be directly involved in oxidative metabolism. [38] emphasized that in the same time frame bio-accumulated toxic metals modified the general metabolism in the hepatopancreas of mussels and suggested the possibility of Cd binding with glutathione.

[64] reported that the activity levels of glutathione-s-transferase, glutathione peroxidase and supperoxide dismutase in the gills and digestive glands of blue mussels (Mytilus edulis) collected in North-West coast of France were used as biomarkers. [64] and [25] found out that, the significant decrease in the activity of tissue enzymes, suggesting some kind of functional damage in the cells lead to the leakage of these cellular enzymes into the extracellular fluid. These findings are in full agreement with those of the present study suggesting that there was a strong relationship between inhibition of tissue enzymes activities and tissue damage. Enzymatic defenses involved in protection from oxygen radical damage were determined in gills and mantle in Bathymodiolus azoricus. SOD level was higher in gills whereas GPx level was higher in the mantle [65]. Variations in the physiology of animal might have been affected by the intake of metals by the organisms. Metal intake may differ in relation to ecological needs, metabolism of animals. In the present study, the average concentrations of $\mathrm{Cu}$ in all dissected organs — mantle, gills and digestive gland—of Lithophaga lithophaga were lower than that stated by [17] for soft tissues. The present study reported that in terms of geographical locations the highest values appeared in the reference site is may be due to the discharge of untreated domestic wastes and other coastal and human activities which give rise to high metal concentration.

$\mathrm{Cu}$ in the gills of Bathymodiolus azoricus from reference sites was higher when compared with similar tissues of coastal mussels, Mytilus edulis and Mytilus galloprovincialis from heavily polluted environments [37]. It has been reported that in the uncontaminated conditions the hepatopancreas demonstrates the highest values of toxic metals as a result of its major role in the uptake of metals from food [36]. The major environmental problem in the coastal area is directly related to the impact of domestic effluents [3]. The average concentrations of $\mathrm{Cu}$ and $\mathrm{Cd}$ in all dissected organs-mantle, gills and digestive gland—of Lithophaga lithophaga in the present study were lower than that reported by [17] $7800 \mu \mathrm{g} / \mathrm{g}$ for soft tissues of shellfish. The surveys of contaminants in shellfish conducted by Agency for Toxic Substances and Disease Registry [17] which reported the mean of Cd level for shellfish as $360 \mu \mathrm{g} / \mathrm{g}$ dry weight. 
In the present study the antioxidant enzymes measured in the gill, mantle and the digestive glands collected from the clams showed fluctuations at the different study areas as shown. Variations in the physiology of animal might have been affected by the intake of metals by the organisms [25]. The present study is in agreement with that of the reference [25], as, metal intake may differ in relation to ecological needs, metabolism of animals. Environmental stress may cause changes in cellular function that alter the physiology in organisms. The present study used a set of biomarkers to assess the state of health of Lithophaga lithophaga in the inspected locations. It is strongly recommended that the discharges of waste products of many industrial factories and the wastes of summer season and facilities is to be prevented from pouring directly or indirectly into Alexandria coast before subjected to several treatments and refinement procedures to reduce their harmful effects on the marine biota and the ecosystem as a whole. It is may be suggested disturbances in the functioning of the internal organs as a consequence of protein synthesis.

\section{Conclusion}

It is concluded from the present study that the toxic effects of heavy metals are the result of interaction between the metal, the physical environment and the biota. It is concluded here that there is no risk to eat clam collected from Alexandria coast from the chosen locations as the levels of different heavy metal concentrations in tissues are below the safety levels reported by [17].

\section{References}

[1] Huanxin, W., Lejum, Z. and Presley, B.J. (2000) Bioaccumulation of Heavy Metals in Oysters (Crassostrea virginica) Tissue and Shell. Environmental Geology, 39, 1216-1226. http://dx.doi.org/10.1007/s002540000110

[2] Madkour, H.A. (2005) Distribution and Relationships of Heavy Metals in the Gaint Clam (Tridacna maxima) and Associated Sediments from Different Sites in the Egyptian Red Sea Coast. Egyptian Journal of Aquatic Research, 31, 45-59.

[3] Bebianno, M.J., Company, F., Serafim, A., Camus, L., Cosson, R.P. and Fiala, M.A. (2005) Antioxidant Systems and Lipid Peroxidation in Bathymodiolus zoricus from Mid-Atlantic Ridge Hydrothermal Vent Fields. Aquatic Toxicology, 75, 354-373. http://dx.doi.org/10.1016/j.aquatox.2005.08.013

[4] Shakweer, L.M., Shiridah, M., Fahmi, M. and El Fatah, A. (2006) Distribution and Concentrations of Trace Elements along the Mediterranean Coastal Water of Egypt. Egyptian Journal of Aquatic Research, 32, 95-127.

[5] Otchere, F.A. (2003) Heavy Metals Concentrations and Burden in the Bivalves (Anadara senilia) Senilis, Crassostrea tulipa and Perna perna) from Lagoons in Ghana: Model to Describe Mechanism of Accumulation/Excretion. African Journal of Biotechnology, 2, 280-287.

[6] El Moselhy, Kh.M. and Yassien, M.H. (2005) Accumulation Patterns on Heavy Metals in Venus Clams, Paphia undulate (Born, 1780) and Gafrarium pectinatum (Linnaeus, 1758), from Lake Timsah, Suez Canal, Egypt. Egyptian Journal of aquatic Research, 31, 13-28.

[7] Sokolova, I.M., Evans, S. and Hughes, F.M. (2004) Cadmium-Induced Apoptosis in Oyster Haemocytes Involves Disturbance of Cellular Energy Balance but No Mitochondrial Permeability Transition. The Journal of Experimental Biology, 207, 3369-3380. http://dx.doi.org/10.1242/jeb.01152

[8] Kremling, K. (1983) The Behavior of Zn, Cd, Ni, Co, Fe, and Mn in Anoxic Baltic Waters. Marine Chemistry, 13, 87-108. http://dx.doi.org/10.1016/0304-4203(83)90019-1

[9] Bernhard, M. (1976) Sampling and Analysis of Biological Material. Manual of Methods in Aquatic Environment Research. FAO Fisheries Technical Paper 158, 124 p.

[10] Grasshoff, K. (1976) Methods of Sea Water Analysis. Verlag Chemie, New York, 317 p.

[11] Misra, H.P. and Fridovich, I. (1972) The Role of Superoxide Anion in the Autoxidation of Epinephrine and a Simple Assay for Superoxide Dismutase. Journal of Biological Chemistry, 247, 3170-3175.

[12] Jakoby, W.B. (1985) Glutathione Transferase: An Overview. In: Colowick, S.P. and Kaplan, N.O., Eds., Methods in Enzymology, Academic Press, New York, 495-504.

[13] Flohe, L. and Gunzler, W.A. (1984) Assays of Glutathione-Peroxidase. Methods in Enzymology, 105, 114-121. http://dx.doi.org/10.1016/S0076-6879(84)05015-1

[14] Hassan, M.A. and Nadia, A.A. (2000) Trace Metals in Fish, Mussels, Shrimps, and Sediment from Red Sea Coast of Yamen. Bulletin of the National Institute of Oceanography and Fisheries, 26, 339-353.

[15] Stentiford, G. (2006) Disease Interactions and Pathogen Exchange between Farmed and Wild Aquatic Animal Popula- 
tions-A European Network. Cefas Weymouth Laboratory, Weymouth.

[16] Sokolova, I.M. (2004) Cadmium Effects on Mitochondrial Function Are Enhanced by Elevated Temperatures in a Marine Poikilotherm, Crassostrea virginica Gmelin (Bivalvia: Ostereidae). Journal of Experimental Biology, 207, 26392648. http://dx.doi.org/10.1242/jeb.01054

[17] ATSDR (Agency for Toxic Substances and Disease Registry) (2003) Toxicological Profile for Copper. US Department of Health and Human Services, Public Health Service, Washington DC.

[18] Peng, R., Tang, B., Zeng, Z., Yang, X. and Zhang, Z. (2001) Direct Determination of Pb, Zn and Cd in Environmental and Biological Samples by FAAS. Spectroscopy and Spectral Analysis, 21, 77-80.

[19] Rebelo, M.F., do Amaral, M.C.R. and Pfeiffer, W.C. (2003) High Zn and Cd Accumulation in the Oyster Crassostrea rhizophorae and Its Relevance as a Sentinel Species. Marine Pollution Bulletin, 46, 1354-1358. http://dx.doi.org/10.1016/S0025-326X(03)00244-3

[20] Segnini de Bravo, M.I. (2003) Influence of Salinity on the Physiological Conditions in Mussels, Perna perna and Perna viridis (Bivalvia: Mytilidae). Revista de Biologia Tropical, 51, 153-158.

[21] Nessim, R.B., Masoud, M.S. and Maximous, N. (2005) Water Characteristics of Alexandria Hot Spots. Egyptian Journal of Aquatic Research, 31, 25-37.

[22] Zyadah, M., Ibrahim, M. and Madkour, A. (2004) Impact of Environmental Parameters on Benthic Invertebrates and Zooplankton Biodiversity of the Eastern Region of Delta Coast at Damietta, Egypt. Egyptian Journal of Aquatic Biology and Fisheries, 8, 37-52.

[23] Zyadah, M. and Serag, M. (2001) Biodiversity and Management in Western Section of El-Salam Canal, Egypt. Journal of Union of Arab Biologists, 16, 411-426.

[24] Abou Taleb, A.E.A., Akel, M.M., Nessim, R.B. and Ramadan, M.H. (2004) Assessment of Some Heavy Metals and Their Accumulation in Marine Organisms in Alexandria Coastal Environment. Master Thesis, High Institute of Public Health, Alexandria University, Alexandria, 260 p.

[25] Tomazelli, A.C., Martinelli, L.A., Avelar, W.E.P., de Camargo, P.B., Fostier, A.H., Ferraz, E.S.B., Krug, F.J. and Junior, D.S. (2003) Biomonitoring of Pb and Cd in Two Impacted Watersheds in Southeast Brazil Using the Freshwater Mussel Anodontites trapesialis (Lamarck, 1819) (Bivalvia: Mycetopodidae) as a Biological Monitor. Brazilian Archives of Biology and Technology, 46, 673-684. http://dx.doi.org/10.1590/S1516-89132003000400022

[26] Khair-Allah, D.A., Matta, C.A., Yousif, W.B., Sorour, J.M., Shonouda, M.L. and Abdel Razik, H.A. (2006) Impact of Pollution on the Water Bug Sphaerodema urinator (Dofour, 1833) Inhebting Lakes Mariut and Edku. Ph.D. Thesis, Faculty of Science, Alexandria University, Alexandria.

[27] Radwan, E.H., Hashem, H.O. and ElGendi, A.H. (2009) Impact of Marine Pollution on Pinctadaradiata. Ph.D. Thesis, Faculty of Science, Alexandria University, Alexandria.

[28] Oliver, F., Ridd, M. and Klumpp, D. (2002) The Use of Transplanted Cultured Tropical Oysters (Saccostrea commercialis) to Monitor Cd Levels in North Queensland Coastal Waters (Australia). Marine Pollution Bulletin, 44, 10511062. http://dx.doi.org/10.1016/S0025-326X(02)00157-1

[29] Koschinsky, A., Borowski, C. and Halbach, P. (2003) Reactions of the Heavy Metal Cycle to Industrial Activities in the Deep Sea: An Ecological Assessment. International Review of Hydrobiology, 88, 102-127.

[30] Ramadan, Sh.E., KheirAllah, A.M. and Abdel-Salam, Kh.M. (2006) Factors Controlling Marine Fouling in Some Alexandria Harbor, Egypt. Mediterranean Marine Science, 7, 31-54.

[31] USEPA: United States Environmental Protection Agency (2005) Current National Recommended Water Quality Criteria. Fact Sheet, Washington DC, 25 May 2005.

[32] Abdul Nabi, B.M., Adham, Kh.G., Sheweita, S.A. and Ibrahim, H.M. (2002) Xenobiotics and the Susceptibility of Oreochromis niloticus (Linnaeus, 1757) from Lakemaryut to Environmental Interactions and Hepatic Biotransformations. M.Sc. Thesis, Faculty of Science, Alexandria University, Alexandria.

[33] El Sikaily, A., Khaled, A. and El-Nemr, A. (2003) Heavy Metals Monitoring Using Bivalves from Mediterranean Sea and Red Sea. Environmental Monitoring and Assessment, 98, 41-58.

[34] Chou, C.L., Paon, L.A., Moffatt, J.D., Buzeta, M.I., Fenton, D. and Rutherford, R.J. (2004) Distribution of Contaminants in Biota and Sediments in the Musquash Estuary, Atlantic Canada, Marine Protected Area Site Initiative and Contaminant Exclusion Zone. Marine Pollution Bulletin, 48, 884-893.

[35] MacFarlane, G.R., Markich, S.J., Linz, K., Gifford, S., Dustan, R.H., O’Conner, W. and Russell, R.A. (2005) The Akoya Pearl Oyster Shell as an Archival Monitor of Lead Exposure. Environmental Pollution, 143, 166-173. http://dx.doi.org/10.1016/j.envpol.2005.10.042

[36] Znidaric, M.T., Falnoga, I., Skreblin, M. and Turk, V. (2005) Induction of Metallothionein-Like Proteins by Mercury and Distribution of Mercury and Selenium in the Cells of Hepatopancreas and Gill Tissues in Mussel Mytilus gallo- 
provincialis. Biological Trace Element Research, 111, 120-140.

[37] Pruski, A.M. and Dixon, D.R. (2003) Effects of Cadmium on Nuclear Integrity and DNA Repair Efficiency in the Gill Cells of Mytilus edulis L. Aquatic Toxicology, 57, 127-137.

[38] Geret, F., Jouan, A., Turpin, V., Bebianno, M.J. and Cosson, R.P. (2002) Influence of Metal Exposure on Metallothionein Synthesis and Lipid Peroxidation in Two Bivalve Molluscs: The Oyster (Crassostrea gigas) and Mussel (Mytilus edulis). Aquatic Living Resources, 15, 61-66. http://dx.doi.org/10.1016/S0990-7440(01)01147-0

[39] Bonneris, E., Giguere, A., Perceval, O., Buronfosse, T., Masson, S., Hare, L. and Campbell, P.G. (2005) Role of Calcium Concretions in Metal Sequestration: Bivalve, Pyganodon grandis.

[40] Blasco, J. and Puppo, J. (2005) Effect of Heavy Metals (Cu, Cd and Pb) on Aspartate Alanine Aminotransferase in Ruditapes philippinarum (Mollusca: Bivalvia). Comparative Biochemistry and Physiology Part C, Pharmacology, Toxicology and Endocrinology, 122, 253-263.

[41] Rajalakshmi, S. and Mohandas, A. (2005) Copper-Induced Changes in Tissue Enzymes Activity in a Freshwater Mussel. Ecotoxicology and Environmental Safety, 62, 140-143. http://dx.doi.org/10.1016/j.ecoenv.2005.01.003

[42] Soazig, L. and Marc, L. (2003) Potential Use of the Levels of the mRNA of a Specific Metallothionein Isoform (MT-20) in Mussel (Mytilus edulis) as a Biomarker of Cadmium Concentration. Marine Pollution Bulletin, 46, 14501455. http://dx.doi.org/10.1016/S0025-326X(03)00283-2

[43] Geffard, O., Budzinski, H. and His, E. (2004) The Effects of Elutriates from PAH and Heavy Metal Polluted Sediments on Crassostrea gigas (Thunberg) Embryogenesis Larval Growth and Bio-Accumulation by the Larvae of Pollutants from Sedimentary Origin. Ecotoxicology, 11, 403-416. http://dx.doi.org/10.1023/A:1021024415695

[44] Galay Burgos, M. and Rainbow, P.S. (2001) Availability of Cadmium and Zinc from Sewage Sludge to the Flounder, Platichthys flesus, via a Marine Food Chain. Marine Environmental Research, 51, 417-439. http://dx.doi.org/10.1016/S0141-1136(00)00249-X

[45] Gagné, F., Blaise, C., Aoyama, I., Luo, R., Gagnon, C., Couillard, Y., Campbell, P. and Slazar, M. (2002) Biomarker Study of a Municipal Effluent Dispersion Plume in Two Species of Freshwater Mussels. Environmental Toxicology, 17, 149-159. http://dx.doi.org/10.1002/tox.10046

[46] Fung, C.N., Lam, J.C., Zheng, G.J., Connel, D.W., Monirith, I., Tanabe, S., Richardson, B.J. and Lam, P.K. (2004) Mussel-Based Monitoring of Trace Metal and Organic Contaminants along the East Coast of China Using Perna Viridis and Mytilus edulis. Environmental Pollution, 127, 203-216. http://dx.doi.org/10.1016/j.envpol.2003.08.007

[47] Storelliu, M.M., Storelli, A. and Marcotrigiano, G.O. (2000) Heavy Metals in Mussels (Mutilus galloprovincialis) from the Ionian Sea, Italy. Journal of Food Protection, 63, 273-276.

[48] El-Moselhy, K.M. and Yassien, M.H. (2005) Accumulation Patterns of Heavy Metals in Venus Clams, Paphia undulata (Born, 1780) and Gafraium pectinatum (Linnaeus, 1758), from Lake Timsah Suez Canal, Egypt. Egyptian Journal of Aquatic Research, 31, 13-28.

[49] Mos, L., Jack, J., Cullon, D., Montour, L., Alleyne, C. and Ross, P.S. (2004) The Importance of Marine Foods to a Near-Urban First Nation Community in Coastal British Columbia, Canada: Toward a Risk-Benefit Assessment. Journal of Toxicology and Environmental Health, Part A, 67, 791-808.

[50] Rainbow, P.S., Amiard-Triquet, C., Amiard, J.C., Smith, B.D. and Langston, W.J. (2000) Observations on the Interaction of Zinc and Cadmium Uptake Rates in Crustaceans (Amphipods and Crabs) from Coastal Sites in U.K. and France Differentially Enriched with Trace Metals. Aquatic Toxicology, 50, 189-204. http://dx.doi.org/10.1016/S0166-445X(99)00103-4

[51] Bastamante, P., Cosson, R.P., Gallien, I., Caurant, F. and Miramand, P. (2002) Cadmium Detoxification Processes in the Digestive Gland of Cephalopods in Relation to Accumulated Cadmium Concentrations. Marine Environmental Research, 53, 227-241. http://dx.doi.org/10.1016/S0141-1136(01)00108-8

[52] Jing, G., Li, Y., Xie, L. and Zhang, R. (2006) Metal Accumulation and Enzyme Activities in Gills and Digestive Gland of Pearl Oyster Exposed to Copper. Comparative Biochemistry and Physiology Part C: Toxicology \& Pharmacology, 144, 184-190.

[53] Snyman, R.G., Reinecke, A.J. and Reinecke, S.A. (2005) Quantitative Changes in the Digestive Gland Cells of the Snail Helix aspersa after Exposure to the Fungicide Copper Oxychloride. Ecotoxicology and Environmental Safety, 60, 47-52. http://dx.doi.org/10.1016/j.ecoenv.2003.11.008

[54] Odzak, N., Zvonaric, T., Gaspic, Z.K., Horvat, M. and Baric, A. (2000) Biomonitoring of Mercury in the Kastela Bay Using Transplanted Mussels. Science of the Total Environment, 261, 61-68.

[55] Sokolowski, A., Wolowicz, M., Hummel, H., Smolarz-Gorska, K., Fichet, D., Radenac, G., Thiriot-Quievreux, G. and Naniesnik, J. (2005) Abnormal Features of Macoma balthica (Bivavia) in the Baltic Sea: Alerting Symptoms of Environmental Adversity. Marine Pollution Bulletin, 49, 17-22. 
[56] Soto, M., Ireland, M.P. and Marigomez, I. (2000) Changes in Mussels Biometry on Exposure to Metals: Implications in Estimation of Metal Bioavailability in "Mussel-Watch" Programmes. Science of the Total Environment, 247, 175187. http://dx.doi.org/10.1016/S0048-9697(99)00489-1

[57] De-Mora, S., Fowler, S.W., Wyse, E. and Azemard, S. (2004) Distribution of Heavy Metals in Marine Bivalves, Fish and Coastal Sediments in the Gulf and Gulf of Oman. Marine Pollution Bulletin, 49, 410-424. http://dx.doi.org/10.1016/j.marpolbul.2004.02.029

[58] Zauke, G.P., Clason, B., Savinov, V.M. and Savinova, T. (2003) Heavy Metals of Inshore Benthic Invertebrates from the Barents Sea. Science of the Total Environment, 306, 99-110. http://dx.doi.org/10.1016/S0048-9697(02)00487-4

[59] Cöksu, M.Z.L., Akar, M., Cevic, F. and Findik, O. (2005) Bioaccumulation of Some Heavy Metals (Cd, Fe, Zn, Cu) in Two Bivalvia Species (Pinctada radiata Leach, 1814 and Brachidontes pharaonis Fischer, 1870). Turkish Journal of Veterinary and Animal Sciences, 29, 89-93.

[60] El Moselhy, Kh.M.I. (2000) Accumulation of Copper, Zinc, Cadmium, and Lead in Some Fish Species from the Gulf of Suez. Egyptian Journal of Aquatic Biology and Fisheries, 4, 235-249.

[61] Otsvik, P.A., Gundersen, P., Andersen, R.A. and Zachariassen, K.E. (2000) Metals Accumulation and Metallothionein in Two Populations of Brown Trout, Salmo trutta, Exposed to Different Natural Water Environments during a Run-Off Episode. Aquatic Toxicology, 50, 301-316. http://dx.doi.org/10.1016/S0166-445X(00)00094-1

[62] Yokoyama, A. and Park, H.D. (2003) Depuration Kinitics and Persistence of the Cyanobacterial Toxin Microcystin-LR in the Freshwater Bivalve Unio douglasiae. Environmental Toxicology, 18, 61-67. http://dx.doi.org/10.1002/tox.10102

[63] Manduzio, H., Monsinjon, T., Galap, C., Leboulenger, F. and Rocher, B. (2004) Seasonal Variations in Antioxidant Defences in Blue Mussels Mytilus edulis Collected from a Polluted Area: Major Contributions in Gills of an Inducible Isoform of Cu/Zn-Superoxide Dismutase and of Glutathione-S-Transferase. Aquatic Toxicology, 70, 83-93.

[64] Stohs, J.S., Bagchi, D., Hassoun, E. and Bagchi, M. (2000) Oxidative Mechanisms in the Toxicity of Chromium and Cadmium Ions. Journal of Environmental Pathology, Toxicology and Oncology, 19, 201-213.

[65] El Gendy, A.H., Adham, Kh. and Ibrahim, H.M. (2003) Biomarkers of Pollution in the Clam, Scapharca inaequivalvis (Bruguiere, 1789). Ph.D. Thesis, Faculty of Science, Alexandria University, Alexandria. 
Scientific Research Publishing (SCIRP) is one of the largest Open Access journal publishers. It is currently publishing more than 200 open access, online, peer-reviewed journals covering a wide range of academic disciplines. SCIRP serves the worldwide academic communities and contributes to the progress and application of science with its publication.

Other selected journals from SCIRP are listed as below. Submit your manuscript to us via either submit@scirp.org or Online Submission Portal.
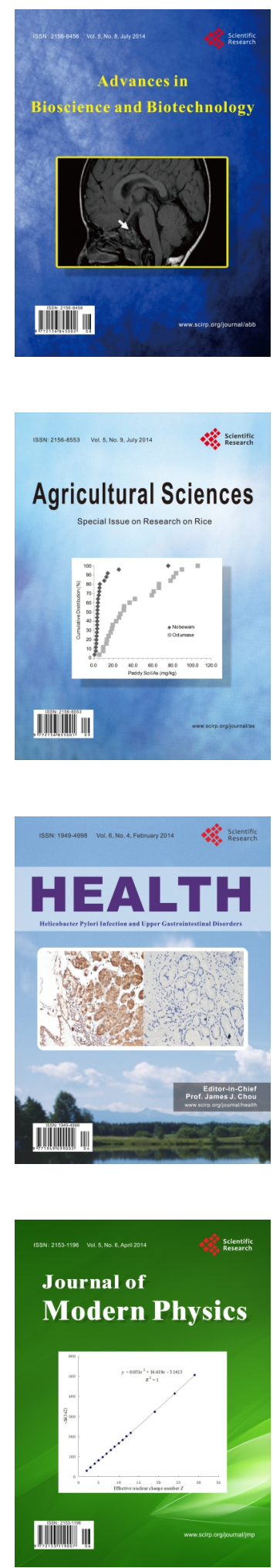
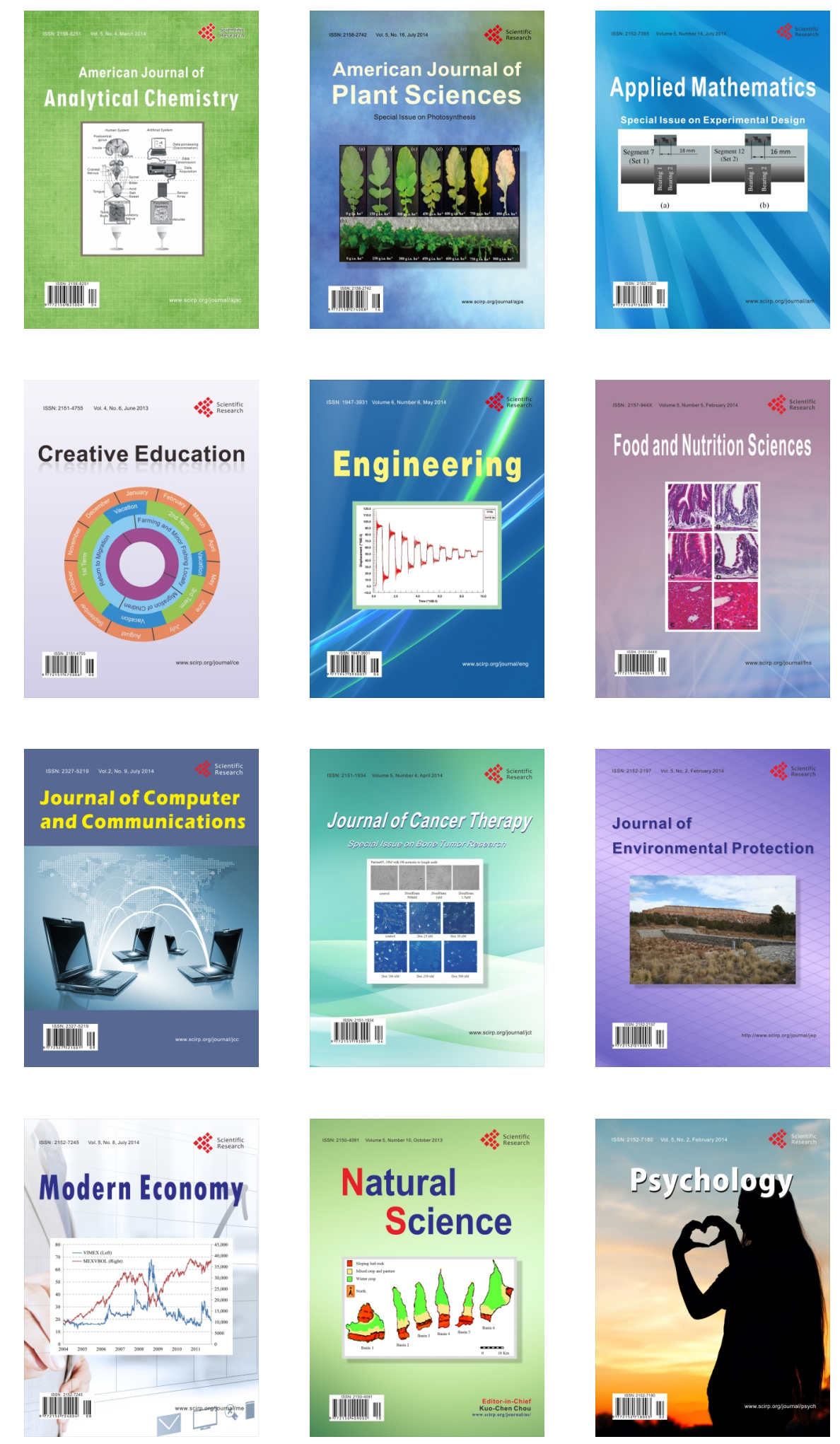